\title{
Factors Influencing for Severity of Road Traffic Accidents in Sri Lanka
}

\author{
D. S. Kodithuwakku ${ }^{*}$ and T. S. G. Peiris ${ }^{2}$ \\ ${ }^{1}$ Department of Social Statistics, University of Kelaniya, Sri Lanka \\ ${ }^{2}$ Mathematics Unit, Faculty of Humanities \& Sciences, Sri Lanka Institute of \\ Information Technology \\ *Corresponding Author: dilushik@kln.ac.lk
}

Received: 22nd January 2021 / Revised: 03 ${ }^{\text {rd }}$ March $2021 /$ Published: 30 ${ }^{\text {th }}$ August 2021

CIAppstat-SL2021

\begin{abstract}
Road Traffic Accidents (RTAs) are one of the most prominent public health problems as it is a leading cause of death by injury and all deaths globally. This study therefore intended determine the factors associated with severity of RTAs in Sri Lanka (2005 2019) based on data driven decision making (DDDM) which would be useful for decision makers. Analysis of frequency tables with Chi-square statistics and binary logistic regression analysis were applied to derive the required inferences. When the variables were considered separately, all attributes of road characteristics, time \& environmental characteristics vehicle characteristics and human \& accident characteristics have significant association with severity of accident except gender of the driver. The fitted binary logistic model revealed that wet road surface, night with improper street lighting, night with good street lighting, rural area, normal weekend, holiday, alcohol test not tested, accidents due to the lack of attention of the driver, two wheels vehicles, age of vehicle less than 10 years and driver's age under the age of 18 years have significantly contributed to occurrences of fatal accidents. The odds of happening fatal accidents in wet road surface 1.109 times higher than that it occurs in dry road surface. The odds of happening fatal accidents during night with improper street lighting is 1.518 times higher than that it occurs during daylight. The inferences derived from this study would be very useful for policy makers in order to minimize RTAs in Sri Lanka.
\end{abstract}

Keywords: Fatal Accidents, Road Traffic Accidents, Severity of Accident 


\section{Introduction}

Road Traffic Accidents (RTAs) are one of the most prominent problems related to well-being of the community which causes deaths through injury worldwide. It remains an ever-increasing trend and the alarming numbers of fatality recorded globally as well as in Sri Lanka (Amarasinghe and Dharmaratne, 2019; WHO, 2018a). The World Health Organization (WHO) accentuated that, RTAs are a largely neglected child health problem as a large number of children and young adults between the age limit of 5 - 29 die as a result of RTAs (WHO, 2018a). RTAs place eighth as a prominent cause of death for people of all age groups exceeding the amount of deaths caused by HIV/AIDS, Tuberculosis, and Diarrheal Diseases. Not only cause a large number of deaths but also create a loss of material in a physical and economic sense. In comparison to the other leading causes of death in Sri Lanka, RTA is a controllable public health, economic and social problem. Yet, without sufficient knowledge of the seriousness of the problem, the risk of death and injury involved, the ability to carry out context-specific and appropriate interferences are thoroughly limited (WHO, 2018a). Furthermore, the annual deaths by RTAs surpasses that of due to HIV/AIDS, Tuberculosis, and Diarrheal diseases; yet the political commitment and financial investments given to ensure road safety is not sufficient (IHME, 2018; WHO, 2018a). Despite traffic law implementations, technological advances, improvements road infrastructure and improvements in the traffic education systems, the number of traffic fatalities have not decreased substantially over the year.

\section{Risk Factors of RTAs}

Multiple scholars (Kumarage et al., 2000; Komba., 2006; Komada et al., 2013) have carried out many studies to recognize the elements associated with fatal accidents. Among them, Kumarage et al. (2000) claimed that accidents related to speed are the most contributory to deadly accidents in Sri Lanka. Furthermore, Komba (2006), stated that defects in vehicles, driving aggressively, and driving on the wrong side of the road were major contributors of deadly accidents in Tanzania. A study done by Komada et al. (2013) found that slept deprivation among drivers is a significant contributor to fatal accidents. Parallel findings have also been made by Lucidi et al. (2013); stated that sleep related accidents are avoidable yet remain a major cause of traffic accidents. Their study found that young and inexperienced drivers are more vulnerable to RTAs whereas non-urban roads have more sleep-related accidents.

In addition to the above facts, drunk driving is also considered one of the most significant causes of RTAs in many countries. Petrie et al. (2011) studied the effect of alcohol consumption on traffic accidents in rural Australia. Findings indicated that the risky use of alcohol and traffic accidents showed a positive correlation. However, 
Callaghan et al. (2013) mentioned that a large number of studies were dedicated to alcohol consumption and driving safety but few focused on the use of drugs. Their study focused on drug-related accidents and fatality rates in California from 1990 to 2005. Results revealed that individuals with alcohol and drug related disorders were at high risk of motor vehicle accidents. Callaghan et al. (2013) suggested that more interventions are required with a primary focus on drug use. A similar study has been carried out by Wilson et al. (2013) to identify the effect of alcohol use and distracted driving as a cause of traffic fatalities. They emphasized the negative effects of this trend in order to form policies to counter distracted driving.

However, it can also be stated that different studies related to RTAs produce varying results and conclusions (Ren, 2013; Jones et al., 2008; Noland, 2003). Ren (2013) stated that RTAs are caused by human error and concluded that human error is a major reason behind RTAs. As an opposite view to the Ren (2013) and Jones et al. (2003) claimed that geographical variations, such as size and age of population, road length, number of cars, per capita income, traffic counts, and material deprivation are important indicators of mortality and morbidity rates in RTAs. The study was carried out based on traffic data of England and Wales, and it demonstrated the importance of a geographical approach rather than a more conventional road section study. Furthermore, Noland (2003) found that there was no direct correlation between infrastructure changes, such as the addition of lanes, change in lane widths, and traffic fatalities. Study suggested that factors such as age, use of alcohol, use of seatbelts, and medical technology played a far more important role than the infrastructure itself. Nevertheless, studies done by different scholars (Conesa et al., 2013; Liu, 2013) in different situations have identified poor lighting, inadequate visibility, improper designs, inefficient traffic administration, bad weather conditions, poorly lit roads, lack of street lighting, absence of warning systems, mobility of the population, traffic density, and the proportion of paved roads, motorways, and express roads as additional risk factors of road fatalities.

Based on the above facts, factors that are associated with severity of RTAs vary from country-to-country and region-to-region. Additionally, factors that affect RTAs also differ due to climate changes, geographical attributes, attitudes of people, and various vehicle conditions. These factors also have the potential to change over time. Thus, deciding the factors associated severity of RTAs with a certain destination is a complex process. For instance, a study conducted by Somasundaraswaran (2006) and Kumarage et al. (2000) mentioned contrasting factors of Sri Lankan RTAs that are no longer particularly relevant to current trends. This is so because road conditions and the manner in which vehicles are used are bound to rapid change. Consequently, the 
factors associated with severity of RTAs may be different in comparison to previous studies. Thus, it is important to identify and provide solutions for the factors influencing for severity RTAs in current Sri Lanka.

Furthermore, not much extensive studies have been carried to understand this problem and as a result, there is a lack of overall understanding of all the contributing factors and their interaction with each other. Thus, it is importance to acknowledge the intensifying situation involving road deaths and injuries. This study therefore focused on stimulating actions to establish road safety within the country through the identification of factors that associated with severity of RTAs in Sri Lanka.

\section{Materials and Methods}

This study consists with panel data (2005 - 2019) of RTAs in Sri Lanka, obtained from the Sri Lanka Police. Analysis of frequency tables with Chi-square statistics and binary logistic regression analysis were applied to derive the required inferences. The goal of using the binary logistic regression in this study to describe the association between accident severity (fatal/non-fatal) and explanatory variables which describe the road, human, vehicle, accident, time and environmental characteristics of RTAs by identifying the best fitted model. The dependent variable (y) denotes its binary category as 1 for fatal accidents and 0 for non-fatal accidents. The explanatory variables explained by the table 1 .

Table 1: Explanatory Variables of the Model

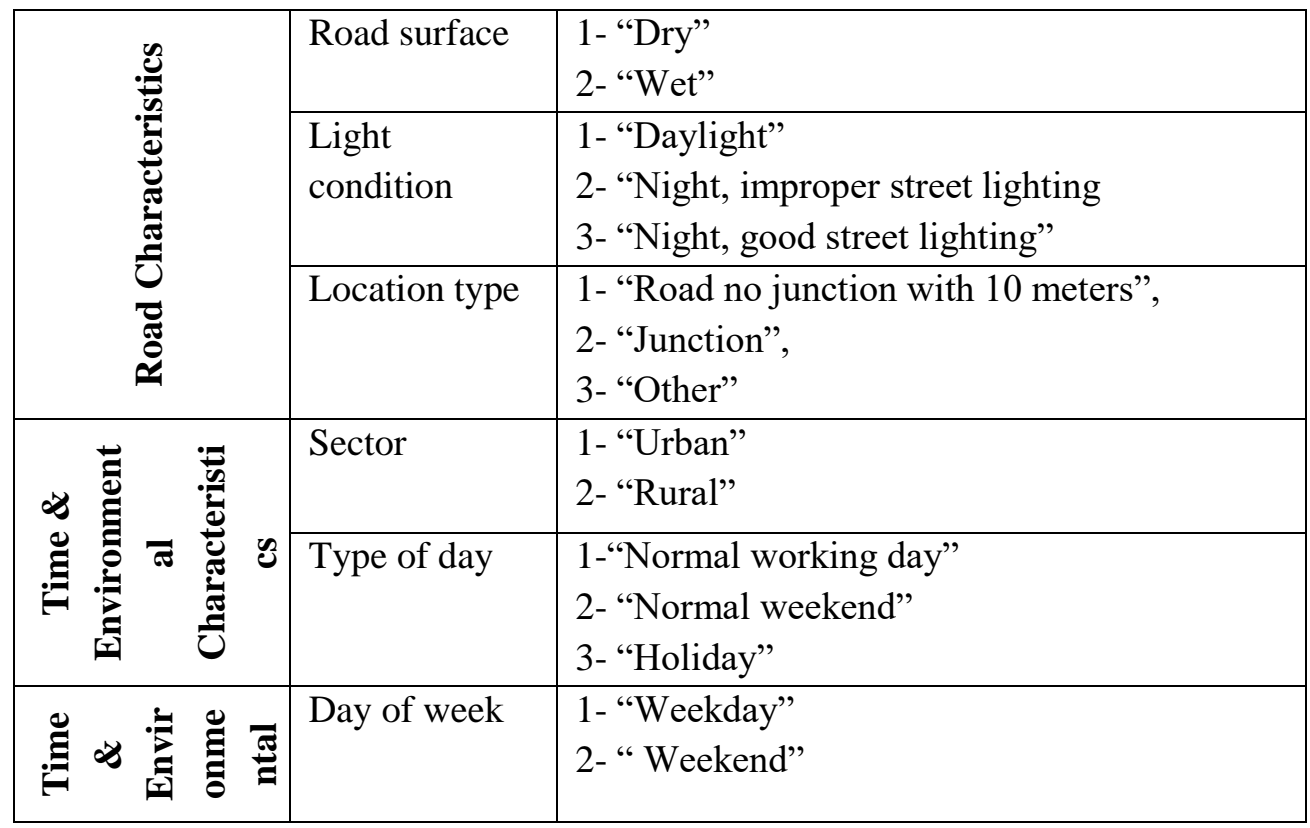


Factors Influencing for Severity of Road Traffic Accidents in Sri Lanka

\begin{tabular}{|c|c|c|}
\hline & Weather & $\begin{array}{l}\text { 1- "Clear" } \\
\text { 2- "Humid" }\end{array}$ \\
\hline \multirow{3}{*}{ 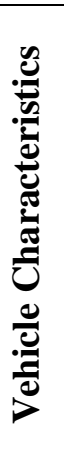 } & Vehicle type & $\begin{array}{l}\text { 1- "Two wheels" } \\
\text { 2- "Three wheels" } \\
\text { 3- "More than three wheels" }\end{array}$ \\
\hline & $\begin{array}{l}\text { Vehicle } \\
\text { ownership }\end{array}$ & $\begin{array}{l}\text { 1- "Private vehicle" } \\
\text { 2- "Government vehicle" } \\
\text { 3- "Service vehicle" }\end{array}$ \\
\hline & Age of vehicle & $\begin{array}{l}\text { 1- "Less than } 10 \text { years" } \\
\text { 2- "10 - } 30 \text { years" } \\
\text { 3- "More than } 30 \text { years" }\end{array}$ \\
\hline \multirow{5}{*}{ 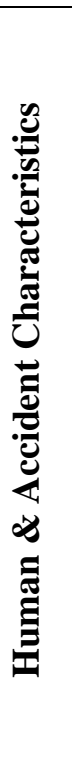 } & Alcohol test & $\begin{array}{l}\text { 1- "No alcohol or below legal limit" } \\
\text { 2- "Over legal limit" } \\
\text { 3- "Not tested" }\end{array}$ \\
\hline & $\begin{array}{l}\text { Validity of } \\
\text { license }\end{array}$ & $\begin{array}{l}\text { 1- "Valid license" } \\
\text { 2-"No license" }\end{array}$ \\
\hline & $\begin{array}{l}\text { Age of the } \\
\text { driver }\end{array}$ & $\begin{array}{l}\text { 1- "Less than } 18 \text { years" } \\
\text { 2- "18 - } 40 \text { years" } \\
\text { 3- " } 40 \text { - } 60 \text { years" } \\
\text { 4- "More than } 60 \text { years" }\end{array}$ \\
\hline & $\begin{array}{l}\text { Gender of the } \\
\text { driver }\end{array}$ & $\begin{array}{l}\text { 1- "Male" } \\
\text { 2- "Female" }\end{array}$ \\
\hline & $\begin{array}{l}\text { Key causes of } \\
\text { RTAs }\end{array}$ & $\begin{array}{l}\text { 1- "Accidents due to negligence of pedestrians } \\
\text { and other external reasons" } \\
\text { 2- "Accidents due to the lack of attention of the } \\
\text { driver" }\end{array}$ \\
\hline
\end{tabular}

\section{Results and Discussion}

\section{Analysis of Variables Separately}

In order to find the association of each variable on RTAs, separate Chi-square tests were carried out initially. Results found that except the gender of the driver, all other categorical variables related to road, time \& environmental, vehicle, human \& accidents characteristics have significant influence $(\mathrm{p}<0.05)$ on the severity of RTAs irrespective of the factors (Table 2).

Table 2: Association between Severity of Accident and each types of Characteristics 
D.S. Kodithuwakku and T.S.G. Peiris

\begin{tabular}{|c|c|c|c|}
\hline $\begin{array}{c}\text { Main } \\
\text { Variable }\end{array}$ & Category & $\begin{array}{c}\% \text { fatal } \\
\text { accident }\end{array}$ & $\begin{array}{l}\text { Test statistic } \\
\text { and p value }\end{array}$ \\
\hline \multicolumn{4}{|c|}{ Road Characteristics } \\
\hline \multirow{2}{*}{$\begin{array}{l}\text { Road } \\
\text { surface }\end{array}$} & Dry & 5.6 & \multirow{2}{*}{$\begin{array}{c}\chi_{1}^{2}=250.507 \\
p=.000\end{array}$} \\
\hline & Wet & 7.7 & \\
\hline \multirow{3}{*}{$\begin{array}{l}\text { Light } \\
\text { condition }\end{array}$} & Day light & 4.7 & \multirow{3}{*}{$\begin{array}{c}\chi_{2}^{2}=2582.049 \\
p=.000\end{array}$} \\
\hline & Night, improper street lighting & 8.4 & \\
\hline & Night, good street lighting & 5.8 & \\
\hline \multirow{3}{*}{$\begin{array}{l}\text { Location } \\
\text { type }\end{array}$} & $\begin{array}{l}\text { Road no junction within } 10 \\
\text { meters }\end{array}$ & 6.2 & \multirow{3}{*}{$\begin{array}{c}\chi_{2}^{2}=650.20 \\
p=.000\end{array}$} \\
\hline & Junction & 4.3 & \\
\hline & Other & 6.3 & \\
\hline \multicolumn{4}{|c|}{ Time \& Environmental Characteristics } \\
\hline \multirow[b]{2}{*}{ Sector } & Urban & 3.9 & \multirow{2}{*}{$\begin{array}{c}\chi_{1}^{2}=3853.123 \\
p=.000\end{array}$} \\
\hline & Rural & 7.8 & \\
\hline \multirow{3}{*}{ Type of day } & Normal working day & 5.5 & \multirow{3}{*}{$\begin{array}{c}\chi_{2}^{2}=227.830 \\
p=.000\end{array}$} \\
\hline & Normal weekend & 6.3 & \\
\hline & Holiday & 7.7 & \\
\hline \multirow{2}{*}{ Day of week } & Weekday & 5.6 & \multirow{2}{*}{$\begin{array}{c}\chi_{1}^{2}=111.179 \\
p=.000\end{array}$} \\
\hline & Weekend & 6.3 & \\
\hline \multirow{2}{*}{ Weather } & Clear & 5.6 & \multirow{2}{*}{$\begin{array}{c}\chi_{1}^{2}=322.418 \\
p=.000\end{array}$} \\
\hline & Humid & 7.7 & \\
\hline \multicolumn{4}{|c|}{ Vehicle Characteristics } \\
\hline \multirow{3}{*}{ Vehicle type } & Two wheels & 6.1 & \multirow{3}{*}{$\begin{array}{c}\chi_{2}^{2}=62.542 \\
p=.000\end{array}$} \\
\hline & Three wheels & 5.6 & \\
\hline & More than three wheels & 5.6 & \\
\hline \multirow{3}{*}{$\begin{array}{l}\text { Vehicle } \\
\text { ownership }\end{array}$} & Private vehicle & 5.7 & \multirow{3}{*}{$\begin{aligned} \chi_{2}^{2} & =6.643 \\
\mathrm{p} & =.036\end{aligned}$} \\
\hline & Government vehicle & 5.9 & \\
\hline & Service vehicle & 6.8 & \\
\hline \multirow{3}{*}{ Vehicle age } & Less than 10 years & 5.9 & \multirow{3}{*}{$\begin{array}{c}\chi_{2}^{2}=32.784 \\
p=.000\end{array}$} \\
\hline & 10 - 30 years & 5.4 & \\
\hline & More than 30 years & 5.3 & \\
\hline \multicolumn{4}{|c|}{ Human \& Accident Characteristics } \\
\hline \multirow{2}{*}{$\begin{array}{l}\text { Validity of } \\
\text { license }\end{array}$} & Valid license & 5.9 & \multirow{2}{*}{$\begin{array}{c}\chi_{1}^{2}=886.503 \\
\mathrm{p}=.000\end{array}$} \\
\hline & No valid license & 1.0 & \\
\hline \multirow{3}{*}{$\begin{array}{l}\text { Age of } \\
\text { driver }\end{array}$} & Less than 18 years & 6.5 & \multirow{3}{*}{$\begin{array}{c}\chi_{3}^{2}=52.202 \\
p=.000\end{array}$} \\
\hline & 18 - 40 years & 5.7 & \\
\hline & $40-60$ years & 5.6 & \\
\hline
\end{tabular}


Factors Influencing for Severity of Road Traffic Accidents in Sri Lanka

\begin{tabular}{|l|l|c|c|}
\hline & More than 60 years & 5.8 & \\
\hline \multirow{5}{*}{$\begin{array}{l}\text { Gender of } \\
\text { driver }\end{array}$} & Male & 5.8 & \multirow{2}{*}{$\begin{array}{c}\chi_{1}^{2}=0.132 \\
\mathrm{p}=.716\end{array}$} \\
\cline { 2 - 3 } Key factors & Female & 5.8 & $\begin{array}{l}\text { of pedestrians and other } \\
\text { external reasons }\end{array}$ \\
\cline { 2 - 3 } & $\begin{array}{l}\text { Accidents due to negligence } \\
\chi_{1}^{2}=430.191 \\
\text { attention of the driver }\end{array}$ & 5.1 & $\mathrm{p}=.000$ \\
\hline
\end{tabular}

Thus table 1 confirmed with $95 \%$ confidence that the percentage of fatal accidents when road surface is wet $(7.7 \%)$ is significantly higher than that when the road is dry (5.6\%). Comparing two binomial distributions separately, it was found that the percentage fatal accident during the night with good street lighting (5.8\%) is significantly higher than during daylight $(4.7 \%)$ and the percentage of fatal accidents when driving in dark with improper street lighting (8.4\%) is significantly higher than driving during night with good street lighting. The percentage of fatal accidents on the road when there is no junction within 10 meters $(6.2 \%)$ is significantly higher than that when there is a junction $(4.3 \%)$.

Results in table 1 indicated that, the percentage of fatal accidents occurrences in rural area $(7.8 \%)$ is significantly higher than in urban area $(3.9 \%)$. In fact, the rate of fatal accidents in rural area is almost double than urban. It was found that the percentage of fatal accidents during normal weekend $(6.3 \%)$ is significantly higher than during normal working day $(5.5 \%)$. Similarly, it was found that the percentage of fatal accidents during holiday $(7.7 \%)$ is significantly higher than in normal weekend. These results were obtained by comparing two binomial distributions separately. This leads to confirm that the percentage of fatal accidents during weekends $(6.3 \%)$ is significantly higher than that during weekdays (5.6\%). Results also confirming the rate of fatal accidents when humid weather $(7.7 \%)$ is significantly higher than that in clear weather $(5.6 \%)$.

The percentage of fatal accidents by two wheels vehicles $(6.1 \%)$ are significantly higher than three wheels $(5.6 \%)$ and four wheels vehicles (5.6\%). Table 1 also indicated that the percentage of fatal accidents by government vehicle $(5.9 \%)$ is significantly higher than by private vehicle $(5.7 \%)$. Similarly, it was found that the percentage of fatal accidents by service vehicle $(6.8 \%)$ is significantly higher than by government vehicle. When comparing three binomial distributions separately, it can be concluded that the percentage of occurring fatal accidents when the vehicle age 10 - 30 years $(5.4 \%)$ is not significantly different from the percentage of fatal accidents 
when the age of the vehicle is more than 30 years. However, the percentage of occurring fatal accidents by vehicle age less than 10 years $(5.9 \%)$ is significantly higher than that of other two types of vehicles.

Results further confirmed that the percentage of fatal accidents occurrences when have a valid license $(5.9 \%)$ is significantly higher than that no valid license $(1.0 \%)$. The percentage of occur fatal accidents occurrences when the driver's age $18-40$ years $(5.7 \%)$ is significantly higher than when the driver's age 40 - 60 years. Moreover, the percentage of fatal accidents occurrences when the driver's age above 60 years $(5.8 \%)$ is significantly higher than when driver's age falls between 40 - 60 years. Similarly, the percentage of fatal accidents occurrences when the driver's age is less than 18 years $(6.5 \%)$ is significantly higher than when the driver's age is more than 60 years. Furthermore, it can be concluded with $95 \%$ confidence that the percentage of occur fatal accidents occurrences due to the lack of attention of driver $(6.4 \%)$ is significantly higher than that occur accidents due to the negligence of pedestrians and other external reasons $(5.1 \%)$.

\section{Analysis of Selected Variables Simultaneously}

To find the combined impact from the best fitted model among the significant variables using Chi-square statistics, binary logistics regression was carried out under forward stepwise ward method. The results of the final model are shown in table 2 . In fact, same model was obtained when all the variables, irrespective of the significance were included into the model. The significant of the Hosmer and Lemeshow test statistic concludes that the fitted model is significant at 5\% level. The overall predictive power of the model is very high as $76.8 \%$. The model is shown in equation (1).

Table 3: Properties of the parameters for best fitted binary logistic model

\begin{tabular}{|l|c|r|r|r|r|r|}
\hline Variables & B & S.E. & Wald & df & Sig. & $\operatorname{Exp(B)}$ \\
\hline Road Surface (RS) & .104 & .022 & 22.534 & 1 & .000 & 1.109 \\
\hline $\begin{array}{l}\text { Light Condition } \\
\text { (LC) }\end{array}$ & .417 & .023 & 323.069 & 1 & .000 & 1.518 \\
\hline $\begin{array}{l}\text { LC. Night, improper } \\
\text { street lighting }\end{array}$ & .510 & .013 & 1658.688 & 1 & .000 & 1.666 \\
\hline $\begin{array}{l}\text { LC. Night, good } \\
\text { street lighting }\end{array}$ & -.262 & .016 & 285.407 & 1 & .000 & .769 \\
\hline Location Type (LT) & -.019 & .021 & .817 & 1 & .366 & .981 \\
\hline LT. Junction & & & & & \\
\hline LT. Other & & & & & & \\
\hline
\end{tabular}


Factors Influencing for Severity of Road Traffic Accidents in Sri Lanka

\begin{tabular}{|c|c|c|c|c|c|c|}
\hline Sector $(\mathrm{S})$ & .641 & .013 & 2515.664 & 1 & .000 & 1.899 \\
\hline Type of Day (TD) & & & 108.532 & 2 & .000 & \\
\hline $\begin{array}{l}\text { TD. Normal } \\
\text { weekend }\end{array}$ & .106 & .013 & 66.056 & 1 & .000 & 1.112 \\
\hline TD. Holiday & .258 & .035 & 54.515 & 1 & .000 & 1.294 \\
\hline Vehicle Type (VT) & & & 8.673 & 2 & .013 & \\
\hline VT. Three wheels & -.054 & .021 & 6.806 & 1 & .009 & .947 \\
\hline $\begin{array}{l}\text { VT. More than three } \\
\text { wheels }\end{array}$ & -.031 & .013 & 5.327 & 1 & .021 & .969 \\
\hline $\begin{array}{l}\text { Age of Vehicle } \\
(\mathrm{AV})\end{array}$ & & & 11.051 & 2 & .004 & \\
\hline AV. 10 - 30 years & -.050 & .015 & 10.612 & 1 & .001 & .952 \\
\hline $\begin{array}{l}\text { AV. More than } 30 \\
\text { years }\end{array}$ & -.060 & .073 & .668 & 1 & .414 & .942 \\
\hline Alcohol Test (AT) & & & 930.797 & 2 & .000 & \\
\hline $\begin{array}{l}\text { AT. Over Legal } \\
\text { Limit }\end{array}$ & -.501 & .047 & 111.155 & 1 & .000 & .606 \\
\hline AT. Not Tested & .375 & .015 & 630.880 & 1 & .000 & 1.455 \\
\hline $\begin{array}{l}\text { Validity of License } \\
\text { (VL) }\end{array}$ & $\begin{array}{r}- \\
1.125\end{array}$ & .075 & 227.001 & 1 & .000 & .325 \\
\hline Age of Driver (AD) & & & 18.647 & 3 & .000 & \\
\hline AD. 18 - 40 years & -.070 & .020 & 12.007 & 1 & .001 & .932 \\
\hline AD. 40 - 60 years & -.023 & .022 & 1.056 & 1 & .304 & .977 \\
\hline $\begin{array}{l}\text { AD. More than } 60 \\
\text { years }\end{array}$ & -.019 & .037 & .264 & 1 & .607 & .981 \\
\hline Key Factors (KF) & .090 & .012 & 53.527 & 1 & .000 & 1.094 \\
\hline Constant & $\begin{array}{l}- \\
3.541\end{array}$ & .028 & 16034.845 & 1 & .000 & .029 \\
\hline
\end{tabular}

Hosmer and Lemeshow Test Statistic: $\chi_{8}^{2}=455.72(\mathrm{p}=.000)$

\section{Impact of Levels within Variables on Fatal Accidents}

The results in table 1 indicate that the variables; road surface, light condition, location type, sector, type of day, vehicle type, age of vehicle, alcohol test, validity license, age of driver and key factors of RTAs to predict the outcome variable are significantly associated with severity of accidents when all the variables are taken into consideration simultaneously. 
Based on the results in $7^{\text {th }}$ column of Table 3 model for odd ratio for the occurrence of fatal accident is given in the Equation (1).

$\left(\frac{p}{1-p}\right)=0.029+1.109 * \mathrm{RS}+1.518 *$ LC.Night improper street lighting $+1.666 *$ LC.Night good street lighting $+0.769 *$ LT.Junction $+1.899 * \mathrm{~S}+1.112 *$ TD.Normal weekend $+1.294 *$ TD.Holiday $+0.947 *$ VT.Three wheels $+0.969 *$ VT.More than three wheels $+0.952 *$ AV.10 -30 years $+0.606 *$ AT.Over Legal Limit $+1.455 *$ AT.Not Tested $+0.325 * \mathrm{VL}+0.932 *$ AD. $18-46$ years $+1.094 *$ $\mathrm{KF}$

The odds of happening fatal accidents in wet road surface is 1.1 times higher than that it occurs in dry road surface when all other variables in the model are fixed. The odds of happening fatal accidents during night with improper street lighting is 1.52 times higher than that it occurs during daylight. It is interesting to note the corresponding rate for good street lighting is slightly higher (1.67) with respect during daytime. The odds of occurring fatal accidents are 1.90 times higher in rural area compared to urban area. The odds of happening fatal accidents in normal weekend and that of normal holiday are 1.1 and 1.3 times respectively higher than that it occurs in normal working days. The odds of happening fatal accidents due to the lack of attention of driver is 1.094 times more likely to occurs compare to fatal accidents due to the negligence of pedestrians and other external reasons.

\section{The Probability of Occurrence Fatal Accidents (p)}

Based on the Equation (1), p for given level of significant variables can be estimated from the Equation (2)

$$
\mathrm{p}=\frac{X X}{(1+X X)}
$$

where $\mathrm{XX}$ is the,

\footnotetext{
$0.029+1.109 * \mathrm{RS}+1.518 *$ LC.Night improper street lighting $+1.666 *$ LC.Night good street lighting $+0.769 *$ $*$ LT.Junction $+1.899 * \mathrm{~S}+1.112 *$ TD.Normal weekend $+1.294 *$ TD.Holiday $+0.947 *$ VT.Three wheels $+0.969 *$ VT.More than three wheels $+0.952 *$ AV.10 -30 years $+0.606 *$ AT.Over Legal Limit $+1.455 *$ e $*$ AT.Not Tested $+0.325 * \mathrm{VL}+0.932 *$ AD $.18-46$ years $+1.094 * \mathrm{KF}$
}

As an example, it was found that the probability (fatal/ wet road surface, night with improper street lighting, rural area) when probability (fatal/wet road surface, night with improper street lighting, urban area) $=0.92$. Thus, it can be predicted that the chance of fatal accidents is very high when the road is wet in night with no proper street lighting in rural areas. 


\section{Conclusions \& Recommendations}

\section{Conclusions}

When the variables were considered separately, all attributes of road characteristics, time \& environmental characteristics and vehicle characteristics, human \& accident characteristics have significant association with accident severity except gender of the driver. The fitted binary logistic model revealed that wet road surface, night with improper street lighting, night with good street lighting, rural area, normal weekend, holiday, alcohol test not tested, accidents due to the lack of attention of the driver, two wheels vehicles, age of vehicle less than 10 years and driver's age under the age of 18 years have significantly contributed to occurrences of fatal accidents. The inferences derived from this study can be easily used for proper planning and consequently to reduce the RTAs in Sri Lanka.

\section{Recommendations}

Motorcycles are often involved in collisions with other vehicles. Thus, it is better to set aside a separate lane for them especially in busy roads. Highlight the presence of motorcyclists through methods such as leaving the headlamp on even during daytime and wearing bright upper-torso garments.

Development of effective training methods to instill collision avoidance braking skills for motorcyclists and establishment of interconnected brake systems.

Installation of traffic signals, streetlights, police statues with flashlights and road lighting equipment in rural areas.

Maintenance of high collision concentration locations and hazardous roads.

\section{References}

1. Amarasinghe, P.G. and Dharmaratne, S. D. (2019). Epidemiology of Road Traffic Crashes Reported in the Kurunegala Police Division in Sri Lanka. Sri Lanka Journal of Medicine, 28(1), 10 - 19. http://doi.org/10.4038/sljm.v28i1.102.

2. Callaghan, R. C., Gatley, J. M., Veldhuizen, S., Lev-Ran, S., Mann, R. and Asbridge, M. (2013). Alcohol or Drug-use Disorders and Motor Vehicle Accident Mortality: A Retrospective Cohort Study. Accident Analysis and Prevention, 53, 149 - 155. https://doi:10.1016/j.aap.2013.01.008. 
3. Conesa, J., Cava-Martinez, F. and Fernandez-Pacheco, D. G. (2013). An Agent based Paradigm for Detecting and Acting on Vehicles Driving in the Opposite Direction on Highways. Expert Systems with Applications, 40(13), 5113 - 5124.

4. IHME - Institute for Health Metrics and Evaluation. (2018). Findings from the Global Burden of Disease Study 2017: Seattle. Retrieved from http://www. health data.org /sites/default/files/files/ policy_report/2019/GBD_2017_Booklet.pdf

5. Jones, A., Haynes, R., Kennedy, V., Harvey, I. M., Jewell, T. and Lea, D. (2008). Geographical Variations in Mortality and Morbidity from Road Traffic Accidents in England and Wales, Health \& Place, 14(35), 519 - 535. https://doi:10.1016/j. healthplace.2007. 10.001

6. Komada, Y., Asaoka, S., Abe, T. and Inoue, Y. (2013). Short Sleep Duration, Sleep Disorders and Traffic Accidents. IATSS Research, 37(1), 1-7. https://doi.org/ 10. 1016 /j.ia tssr.2013.06.001

7. Komba, D. D. (2006). Risk Factors and Road Traffic Accidents in Tanzania: A case Study of Kibaha District. Digitala Vetenska Arkivet, 2, 122-428.

8. Kumarage, A. S., Abeygoonawardena, C. R. and Wijesundera, R. (2000). Identifying Causal Factors of Traffic Accidents in Sri Lanka. 94 ${ }^{\text {th }}$ Annual Proceedings of Institute of Engineers Sri Lanka. The Institution of Engineering Sri Lanka.

9. Liu, D. (2013). Comparison of Vulnerable Road Users Involved in Traffic Accidents in China and Developed Countries. ICTIS 2013, 1560-1565.

10. Lucidi, F., Mallia, L., Violani, C., Giustiniani, G. and Persia, L. (2013). The Contributions of Sleep-Related Risk Factors to Diurnal Car Accidents. Accident Analysis and Prevention, 51, 135-140. https://doi:10.1016/j.aap.2012.11.015

11. Noland, R. B. (2003). Traffic Fatalities and Injuries: The Effect of Changes in Infrastructure and other Trends. Accident Analysis \& Prevention, 35(4), 599-611. https://doi.org/10.1016/S0001-4575(02)00040-4.

12. Petrie, D., Doran, C. and Shakeshaft, A. (2011). Willingness to Pay to Reduce Alcohol-Related Harm in Australian Rural Communities. Expert Rev Pharmacoecon Outcomes Res, 11, 351-363. https://doi:10.1586/erp.11.28

13. Ren, Y. (2013). Analysis of Road Traffic Accident Caused by Human Error. ICTIS 2013, 547 - 552.

14. Somasundaraswaran, A. K. (2006). Accidents Statistics in Sri Lanka. International Association of Traffic and Safety Sciences Research, 30(1), 115117. https://doi: 10.1016/s0386-1112(14)60162-x

15. WHO. (2018a). Global Status Report on Road Safety: Summary. Geneva, Switzerland. Retrieved from https://www.who.int/violence_injury_prevention /road_safety_status/ 2018/English-Summary-GSRRS2018.pdf

16. Wilson, F. A., Stimpson, J. P. and Tibbits, M. K. (2013). The Role of Alcohol use on Recent Trends in Distracted Driving. Accident Analysis \& Prevention, 60, 189 - 192. https://doi:10.1016/j.aap.2013.08.025. 